Ekspansi: Jurnal Ekonomi, Keuangan, Perbankan dan Akuntansi

ISSN (Online): 2580-7668 ISSN (Print): 2085-5230

Vol. 11, No. 2 (November 2019), Hal. 179 - 198

\title{
ANALISIS PERBANDINGAN STABILITAS SISTEM PERBANKAN SYARIAH DAN KONVENSIONAL DI INDONESIA
}

\author{
Ahmad Fatoni ${ }^{1}$, Sahabudin Sidiq ${ }^{2}$ \\ ${ }^{1}$ Jurusan Ekonomi Syariah Universitas Sultan Ageng Tirtayasa, Negara \\ ${ }^{2}$ Jurusan Ilmu Ekonomi Universitas Islam Indonesia, Negara \\ Email Korespondensi: ahmadfatoni@untirta.ac.id
}

\begin{abstract}
This study aims to analyze the comparison of Islamic and conventional banking system stability in Indonesia along with the factors that influence it. This study uses panel data regression by taking a sample of 9 of the largest assets of Islamic and conventional banks in Indonesia during the observation period 2010-2016. The analysis tool used is the analysis of Z-score values and panel data regression. The regression results show that simultaneous internal have a significant effect on the stability of the Islamic banking system. Partially the financing variables based on PLS, NPF, LAR, BOPO, Bank Size and GDP have a significant effect on the stability of the Islamic banking system. Meanwhile the panel data regression results show that simultaneous internal factors and external factors have a significant effect on the stability of the conventional banking system. Partially the BI Rate, BOPO, Bank Size, HHI and GDP variables significantly influence the stability of the conventional banking system. The results of a comparative analysis of Islamic and conventional banking system stability in Indonesia through the analysis of Z-score values indicate that the Islamic banking system has better stability than the conventional banking system.
\end{abstract}

Keywords: Sharia Banking Stability, Conventional Banking Stability, Z-score

Abstrak: Penelitian ini bertujuan untuk menganalisis perbandingan stabilitas sistem perbankan syariah dan konvensional di Indonesia beserta faktor yang mempengaruhinya. Penelitian ini menggunakan regresi data panel dengan mengambil sampel 9 aset terbesar bank syariah dan konvensional di Indonesia selama periode observasi 2010-2016. Alat analisis yang digunakan adalah analisis nilai Z-score dan regresi data panel. Hasil regresi menunjukkan bahwa secara simultan faktor internal dan faktor Eksternal berpengaruh signifikan terhadap stabilitas sistem perbankan syariah. Secara parsial variabel pembiayaan berbasis PLS, NPF, LAR, BOPO, Ukuran Bank dan PDB berpengaruh signifikan terhadap stabilitas sistem perbankan syariah. Sementara itu hasil regresi data panel menunjukkan secara simultan faktor internal dan faktor eksternal berpengaruh signifikan terhadap stabilitas sistem perbankan konvensional. Secara parsial variabel BI Rate, BOPO, Ukuran Bank, HHI dan PDB berpengaruh signifikan terhadap stabilitas sistem perbankan konvensional. Hasil analisis perbandingan stabilitas sistem perbankan syariah dan konvensional di Indonesia melalui analisis nilai Z-score menunjukkan bahwa sistem perbankan syariah mempunyai stabilitas yang lebih baik daripada sistem perbankan konvensional.

Kata Kunci: Stabilitas Perbankan Syariah, Stabilitas Perbankan Konvensional, Z-Score.

DOI: $10.35313 /$ ekspansi.v11i2.1350

Riwayat Artikel:

Diterima: 08 - 08 - 2019

Direvisi: $20-11-2019$

Disetujui: 21 - 11 - 2019 


\section{PENDAHULUAN}

Sistem keuangan memegang peranan yang sangat penting dalam perekonomian. Sebagai bagian dari sistem perekonomian, sistem keuangan berfungsi mengalokasikan dana dari pihak yang mengalami surplus kepada yang mengalami defisit. Apabila sistem keuangan tidak stabil dan tidak berfungsi secara efisien, pengalokasian dana tidak akan berjalan dengan baik sehingga dapat menghambat pertumbuhan ekonomi. Pengalaman menunjukkan, sistem keuangan yang tidak stabil, terlebih lagi jika mengakibatkan terjadinya krisis, memerlukan biaya yang sangat tinggi untuk upaya penyelamatannya (Bank Indonesia, 2017). Sistem keuangan Indonesia pernah mengalami ketidakstabilan yang merupakan dampak dari krisis keuangan Amerika Serikat pada tahun 2008. Hal demikian dilihat dari gejolak Indeks Stabilitas Sistem Keuangan (ISSK) yang dapat ditunjukkan pada gambar berikut:

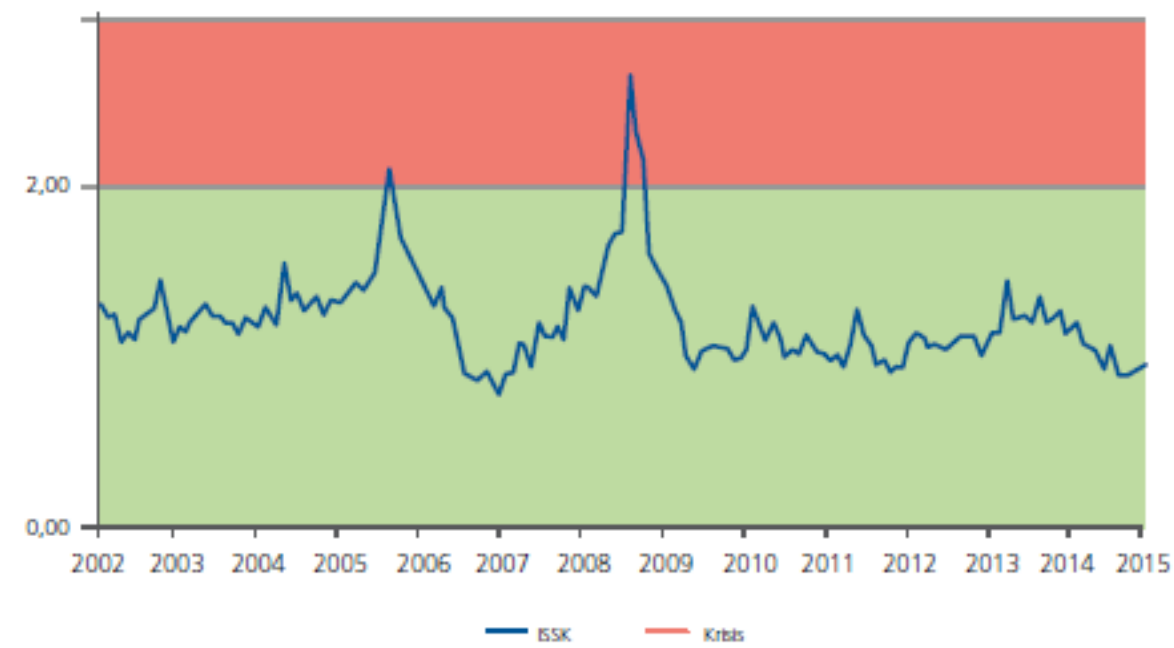

Gambar 1. Indeks Stabilitas Sistem Keuangan

Sumber: Kajian Stabilitas Keuangan Bank Indonesia, 2016

Pada Gambar 1 grafik ISSK memperlihatkan kondisi pasar keuangan Indonesia pada tahun 2008-2009 yang semakin instabil dan termasuk kedalam zona krisis. Indeks Stabilitas Sistem Keuangan sempat melampaui batas indikatif maksimum 2, dengan posisi tertinggi pada bulan November 2008 sebesar 2,43. Krisis keuangan pada tahun 2008 juga mempunyai dampak pada sektor perbankan terutama pada sistem perbankan konvensional. Biaya yang ditanggung oleh pemerintah akibat dari krisis perbankan tersebut sebesar Rp.15.000.000.000.000 sebagai bantuan likuiditas untuk tiga bank nasional berskala besar yaitu Bank Mandiri Tbk, Bank BNI Tbk, dan Bank BRI Tbk (Bank Indonesia, 2010).

Minsky (1992) menganggap ketidakstabilan keuangan menjadi endogen terhadap sistem keuangan konvensional. Dia berpendapat bahwa inovasi keuangan mendestabilisasi menjadi jelas dengan meledaknya boom spekulasi. Ketidakstabilan bank konvensional juga dapat dilihat pada saat suku bunga jangka pendek mengalami peningkatan bersamaan dengan peningkatan suku bunga jangka panjang. Hal demikian tidak hanya dapat menurunkan permintaan atas aset kapital tetapi juga meningkatkan biaya produksi outputnya, yang kemudian menimbulkan penurunan 
investasi. Jika proses penurunan nilai aset, peningkatan biaya aset, dan penurunan profit menyebabkan makin berkurangnya likuiditas sejumlah institusi finansial dan perusahaan, maka pelaku pasar tidak akan mau ikut campur dan krisis akan terus berlanjut (Iqbal dan Mirakhor, 2015).

Sistem perbankan syariah diyakini memberikan solusi untuk membangun sistem perbankan yang lebih stabil dan aman karena terbebas dari riba, maysir dan gharar yang selama ini terdapat dalam sistem perbankan konvensional. Ahmed (2002) berpendapat bahwa proses yang ada pada sistem Profit and Loss Sharing (PLS) dapat membuat bank syariah terhindar dari memburuknya neraca keuangan yang diakibatkan oleh faktor ekonomi. Hal demikian dikarenakan konsep PLS adalah berbagi risiko dari sisi aset ke liabilitas. Stabilnya perbankan syariah juga dapat ditunjukkan dengan banyaknya penelitian secara internasional yang membuktikan bahwa sistem perbankan syariah mempunyai stabilitas yang lebih baik daripada sistem perbankan konvensional. Seperti hasil penelitian yang dilakukan oleh Cihak dan Hesse (2008), Hasan dan Dridi (2010), Boumediene dan Caby (2010). Bahkan Parashar dan Venkatesh (2010) mencatat bahwa bank syariah lebih stabil daripada bank konvensional karena sistem yang mendasarinya.

Meskipun secara internasional dapat membuktikan bahwa bank syariah lebih stabil dibandingkan dengan bank konvensional. Namun demikian penelitian mengenai perbandingan stabilitas keuangan antara bank konvensional dan bank syariah di Indonesia memiliki perbedaan dengan penelitian sebelumnya. Sebagaimana Nur (2014) dan Hassan (2016) yang meneliti perbandingan stabilitas bank syariah dan bank konvensional di Indonesia dengan menggunakan indikator ekonomi makro sebagai variabel independen. Hasil penelitian Nur (2014) menunjukkan bahwa bank syariah tidak lebih stabil dibandingkan dengan bank konvensional. Sementara hasil penelitian Hassan (2016) menunjukkan bahwa bank syariah lebih stabil dibandingkan dengan bank konvensional pada periode krisis. Akan tetapi pada periode setelah krisis bank konvensional lebih stabil dibandingkan dengan bank syariah. Perbedaan hasil pendelitian tersebut menimbulkan keraguan mengenai stabilitas yang ada pada sistem perbankan syariah khususnya di Indonesia. Dengan demikian diperlukan penelitian lebih lanjut mengenai perbandingan stabilitas sistem perbankan syariah dan konvensional di Indonesia beserta faktor yang mempengaruhinya baik faktor yang terdapat didalam institusi perbankan (internal) maupun faktor dari luar (eksternal).

\section{TINJAUAN PUSTAKA}

\subsection{Stabilitas Sistem Keuangan}

Definisi baku stabilitas sistem keuangan secara internasional masih belum terwujud. Namun demikian terdapat beberapa definisi stabilitas keuangan dari berbagai sumber. Deutsche Bundesbank (2003) mendefinisikan stabilitas keuangan sebagai suatu kondisi dimana alokasi sumber dana, menyebar risiko, dan penyelesaian sistem pembayaran yang dapat dilaksanakan walaupun terjadi gejolak, tekanan dan perubahan struktural. Schinasi (2005) mendefinisikan stabilitas sistem keuangan yakni kemampuan sistem keuangan untuk melakukan alokasi sumber dana dalam 
mendukung kegiatan ekonomi, mengelola risiko dan bertahan dari gejolak. Sementara itu, Penelitian tentang perbandingan stabilitas sistem perbankan, sebelumnya sudah pernah dilakukan oleh beberapa peneliti internasional, beberapa diantaranya adalah Rashid dkk (2017) terkait dengan penilaian kontribusi kekuatan finansial terhadap stabilitas keuangan pada bank konvensional dan Islam di Pakistan. Hasil studi menunjukkan bahwa kekuatan finansial seperti income diversity, profitability, asset size, loan asset ratio, dan market consentration memiliki pengaruh yang signifikan terhadap stabilitas keuangan bank. Cihak dan Hesse (2008) mencoba membandingkan stabilitas bank Islam dan bank konvensional dari tahun 1993 - 2004. Sampel yang digunakan pada penelitianya adalah 77 bank syariah dan 397 bank konvensional. Variabel independen dalam penelitian ini menggunakan LAR, Aset, cost to income ratio, income diversity, Indeks Herfindhal, dan governance (GCG) yang merupakan faktor internal serta indikator GDP, inflasi, dan exchange rate. Sedangkan variable dependen yang digunakan adalah Z-score yang merupakan proxy stabilitas bank. Zscore memiliki hubungan negatif dengan kepailitan lembaga keuangan, yaitu kemungkinan nilai aset menjadi lebih rendah daripada nilai utang. Semakin tinggi nilai Z-score mengindikasikan probabilitas kepailitan lembaga keuangan yang semakin rendah (World Bank, 2019). Z-score dapat dihitung dengan menggunakan rumus:

$$
Z-\text { score }=\frac{R O A+C A R}{\sigma_{R O A}}
$$

Dimana Z-score adalah Indeks yang menggambarkan stabilitas bank, ROA adalah Return On Asset bank selama periode observasi yang menggambarkan kemampuan bank untuk menghasilkan laba. CAR (Capital Adequacy Ratio) merupakan modal bank dibanding dengan ATMR (Aktiva Tertimbang Menurut Risiko) untuk melihat tingkat leverage bank. $\sigma_{-}$ROA adalah volatility ROA yang dihitung dengan menggunakan standar deviasi ROA. Dengan demikian, maka diperoleh hasil Z-score sebagai alat ukur stabilitas perbankan baik terhadap sistem perbankan, risiko internal maupun eksternal bank.

Cihak dan Hesse (2008) dalam penelitianya mendapatkan tiga hasil temuan yaitu pertama, bank syariah dengan ukuran kecil (aset kurang dari US\$ 1 milyar) lebih stabil dibandingkan dengan bank konvensional dengan ukuran kecil. Kedua, bank konvensional dengan ukuran besar lebih stabil dibandingkan dengan bank syariah dengan ukuran besar. Ketiga bank syariah dengan ukuran kecil lebih stabil dibandingkan dengan bank konvensional dengan ukuran besar.

\subsection{Profit and Loss Sharing (PLS)}

Nawal Hussein dan Abbas El Hussein (2013) dalam penelitianya menyatakan bahwa sistem PLS pada aset menambah stabilitas sistem keuangan secara keseluruhan. Jika dilihat dari sisi neraca bank Islam yang berbasis aset menempatkan bank-bank Islam lebih dekat pada sektor rill. Secara empiris, belum banyak yang mengkaji hubungan sistem PLS dan stabilitas bank syariah. Sementara itu Kuppusamy (2010) dalam penelitianya menemukan bahwa penggunaan pembiayaan berbasis bagi hasil (PLS) dapat meningkatkan profitabilitas bank. Hal ini dikarenakan keuntungan bank 
akan meningkat seiring dengan peningkatan pendapatan yang diperoleh oleh nasabah (mudharib). Profitabilitas bank yang meningkat tentu akan meningkatkan stabilitas bank dikarenakan profitabilitas juga merupakan komponen dari stabilitas bank.

$\mathrm{H}_{1}$ : Pembiayaan berbasis Profit and Loss Sharing (PLS) berpengaruh positif terhadap stabilitas sistem bank syariah

\subsection{Bi Rate}

BI Rate adalah suku bunga kebijakan yang mencerminkan sikap atau stance kebijakan moneter yang ditetapkan oleh Bank Indonesia dan diumumkan kepada publik Sasaran opersional kebijakan moneter dicerminkan pada perkembangan suku bunga Pasar Uang Antar Bank (PUAB). Pergerakan di suku bunga PUAB ini diharapkan akan diikuti oleh perkembangan di suku bunga deposito, dan pada giliranya suku bunga kredit perbankan. Tingkat suku bunga BI yang meningkat akan meningkatkan potensi instabilitas keuangan. Hal ini diasumsikan karena kredit maupun pembiayaan yang disalurkan oleh perbankan akan terganggu karena debitur mengalami kesulitan dalam pembayaran kembali dikarenakan bunga yang harus dibayarkan saat itu lebih besar daripada periode sebelumnya. Sehingga asumsi penulis bahwa hubungan antara suku bunga dan stabilitas adalah negatif. Sebagaimana hasil penelitian Drifill, dkk (2006) dimana kebijakan bank sentral dengan menurunkan tingkat suku bunga telah meningkatkan stabilitas bank. Demikian juga penelitian yang dilakukan oleh Kraft dan Galac (2007) dengan menggunakan model logit menemukan bahwa suku bunga deposito yang tinggi dan dengan pengawasan yang lemah mengakibatkan instabilitas bank.

\section{$\mathrm{H}_{2}$ : Bi Rate berpengaruh negatif terhadap stabilitas sistem bank konvensional}

\subsection{Non Performing Loan (NPL)}

Dalam mengukur stabilitas bank, juga digunakan pendekatan kualitas aset bank. Rasio NPL mencerminkan risiko portofolio kredit, dimana semakin tinggi angka rasio ini semakin tinggi profil risiko kredit bank yang pada giliranya akan mempengaruhi stabilitas bank secara keseluruhan. Dalam studi empiris Korbi dan Bougatef (2017) menemukan hubungan negatif antara risiko kredit dengan stabilitas bank. Demikian pula menurut Hauben, dkk. (2004) dan Schinasi (2005) menunjukkan bahwa risiko kredit adalah salah satu sumber instabilitas keuangan.

\section{$\mathrm{H}_{3}$ : Non Performing Loan (NPL) berpengaruh negatif terhadap stabilitas sistem} bank syariah dan konvensional

\subsection{Loan to Asset Ratio (LAR)}

Loan to Asset Ratio (LAR) adalah merupakan proxy dari kondisi likuiditas bank. Semakin tinggi angka variabel ini maka semakin besar proporsi aset bank yang ditanamkan dalam bentuk kredit, sehingga menurunkan tingkat likuiditas bank yang pada giliranya berdampak negatif terhadap stabilitas bank dalam mengambil risiko. Beberapa penelitian menggunakan LAR sebagai faktor yang mempengaruhi stabilitas perbankan yakni Cihak dan Hesse (2008), Ali dan Zaheer (2012), dan Siti, dkk. (2013) 
yang menunjukkan bahwa LAR berpengaruh secara signifikan terhadap stabilitas bank. Siti, dkk. (2013) dalam penelitianya menjelaskan bahwa LAR berhubungan negatif terhadap Z-score yang merupakan proxy dari stabilitas keuangan. Ketika LAR menurun maka stabilitas akan meningkat dan risiko kemungkinan terjadinya default akan turun. $\mathrm{H}_{4}$ : Loan to Asset Ratio berpengaruh negatif terhadap stabilitas sistem bank syariah dan konvensional

\subsection{Biaya Operasional Pendapatan Operasional (BOPO)}

Tingkat efisiensi suatu bank sangat erat hubunganya dengan stabilitas bank tersebut. Semakin bank tersebut efisien maka risiko bank untuk default atau kebangkrutan akan semakin menurun. Sebagaimana hasil penelitian yang dilakukan oleh Schaek dan Cihak (2013), efisiensi yang lebih besar mengindikasikan peningkatan stabilitas, karena bank memiliki kualitas aset yang lebih baik dan akan mengurangi risiko default. Umumnya yang menjadi ukuran efisiensi perbankan adalah dengan menggunakan rasio efisiensi. Menurut ketentuan Bank Indonesia (BI) efisiensi operasi diukur dengan menggunakan rasio Biaya Operasional dibandingkan dengan Pendapatan Operasional (BOPO).

$\mathrm{H}_{5}$ : Biaya Operasional Pendapatan Operasional berpengaruh negatif terhadap stabilitas sistem bank syariah dan konvensional

\subsection{Ukuran Bank (Size Bank)}

Secara teoritis, semakin besar ukuran bank, maka semakin baik kemampuan Sumber Daya Manusianya, infrastrukturnya, dan manajemen risikonya, sehingga berdampak positif terhadap stabilitas bank. Leaven, dkk. (2014) dalam penelitianya mengungkapkan bahwa bank-bank besar mendapatkan keuntungan dari skala jangkauan yang lebih luas daripada bank kecil sehingga hal ini dapat mempengaruhi model bisnis dan kinerja mereka. Dengan mempertimbangkan teoritis tersebut maka ukuran perusahaan digunakan sebagai variabel internal yang diduga berpengaruh positif terhadap stabilitas bank. Sementara itu ukuran bank dapat diukur dengan total aset yang dimiliki oleh bank tersebut. Sebagaimana penelitian yang dilakukan oleh Cihak dan Hesse (2008), Siti, dkk. (2013), Allen, dkk (2008), Ali dan Zaheer (2012) yang menggunakan total aset bank sebagai proxy ukuran bank (size bank).

$\mathrm{H}_{6}$ : Ukuran bank (size bank) berpengaruh positif terhadap stabilitas bank syariah dan konvensional

\subsection{Herfindahl Hirschman Index (HHI)}

Isu upaya pencapaian stabilitas berlanjut pada aspek lebih detail tentang sebab dan kondisi yang melatarbelakangi pencapaian stabilitas tersebut. Misalkan Allen, dkk. (2008) meneliti aspek kompetisi perbankan yang merupakan faktor internal dalam stabilitas keuangan. Dalam penelitianya menemukan terdapat keterkaitan antara kompetisi antarbank dengan stabilitas keuangan. Dua pendekatan yang digunakan untuk melacak keterkaitan ini yaitu competition-fragility dan competition-stability. Penelitian ini menghasilkan temuan yang mendukung konsep tradisional competition 
fragility bahwa bank dengan penguasaan pasar kuat kurang mengungkapkan risiko yang dimiliki.

Penggunaan indeks HHI sebagai ukuran tingkat persaingan dalam kaitanya dengan stabilitas bank telah banyak digunakan oleh para peneliti. Diantaranya Cihak dan Hesse (2008), Siti, dkk. (2013), Allen, dkk. (2008), Ali dan Zaheer (2012) dan Rajhi dan Hassairi (2013) menunjukkan bahwa HHI memiliki pengaruh terhadap stabilitas, meskipun mempunyai arah hubungan yang berbeda-beda sesuai dengan pandangan competition-fragillity atau competition-stability.

\section{$\mathrm{H}_{7}$ : $\mathrm{HHI}$ berpengaruh terhadap stabilitas bank syariah dan konvensional}

\subsection{Produk Domestik Bruto (PDB)}

Pertumbuhan ekonomi merupakan salah satu indikator yang sangat penting dalam melakukan analisis pekembangan ekonomi yang terjadi pada suatu negara. Todaro dan Smith (2008) mengatakan bahwa PDB adalah indikator pertumbuhan ekonomi yang mengukur jumlah output final barang (goods) dan jasa (service) yang dihasilkan oleh perekonomian suatu negara, dalam wilayah negara tersebut baik oleh penduduk (warga negara) sendiri maupun bukan penduduk (misalnya perusahaan asing) tanpa memandang apakah produksi output tersebut nantinya akan dialokasikan ke pasar domestik atau luar negeri. PDB atas dasar harga konstan digunakan sebagai variabel eksternal yang mempengaruhi stabilitas bank. Hal ini dengan pertimbangan bahwa secara teoritis pertumbuhan PDB menunjukkan kinerja positif dari suatu perekonomian baik dari sektor rill maupun di sektor finansial. Dengan demikian pertumbuhan PDB dengan menggunakan PDB atas dasar harga konstan akan berpengaruh terhadap stabilitas bank. Sebagaimana penelitian empiris yang dilakukan oleh Siti, dkk. (2013), Ali dan Zaheer (2012), dengan hasil bahwa pertumbuhan PDB mempunyai pengaruh positif terhadap stabilitas bank.

$\mathrm{H}_{8}$ : Produk Domestik Bruto berpengaruh positif terhadap stabilitas sistem bank syariah dan konvensional

\subsection{Inflasi}

Inflasi didefinisikan sebagai kenaikan harga umum secara terus menerus dan persisten dari suatu perekonomian. Pengaruh inflasi yang tinggi tentu akan menyebabkan menurunya pendapatan rill masyarakat sehingga standar hidup masyarakat juga turun, hal ini akan berdampak negatif terhadap kinerja perekonomian secara keseluruhan baik sektor rill maupun sektor finansial. Dengan demikian secara teoritis dapat disimpulkan bahwa semakin tinggi tingkat inflasi cenderung berpengaruh negatif terhadap stabilitas bank. Trabelsi dan Trad (2017) melakukan studi mengenai risk-taking dan profitabilitas pada 94 bank syariah yang beroperasi di 18 negera selama periode 2003-2013, ia menemukan bahwa inflasi mempunyai pengaruh signifikan terhadap stabilitas bank. Akram dan Eirtheim (2008) menunjukkan adanya trade-off antara inflasi dan stabilitas keuangan. Volatilitas hargaharga umum dapat menyebabkan kenaikan suku bunga dan karenanya menurunkan stabilitas bank. 


\section{METODE PENELITIAN}

Penelitian ini menggunakan dua model analisis yaitu analisis regresi data panel dan nilai z-score. Model analisis regresi data panel digunakan untuk mengetahui faktor yang mempengaruhi stabilitas sistem perbankan syariah dan konvensional. Sedangkan analisis nilai $z$-score digunakan untuk membandingkan stabilitas sistem perbankan syariah dan konvensional melalui uji beda rata-rata (independent sample t-tests). Sementara itu, populasi dalam penelitian ini adalah bank umum syariah dan konvensional di Indonesia. Melalui metode purposive sampling maka diambil sampel 9 bank terbesar bank syariah dan konvensional. Jenis data yang digunakan adalah data sekunder, yaitu data semesteran dari periode Juni 2010 sampai dengan Juni 2016. Data ini diperoleh dari laporan publikasi perbankan Otoritas Jasa Keuangan (OJK), Bank Indonesia (BI) dan Badan Pusat Statistik (BPS). Sementara itu spesifikasi model umum untuk stabilitas sistem perbankan syariah dan konvensional adalah sebagai berikut:

$$
\begin{gathered}
\text { Model Stabilitas Sistem Perbankan Syariah } \\
\operatorname{lnZS}_{i t}=\beta_{0}+\beta_{1} P L S_{1 i t}+\beta_{2} N P F_{2 i t}+\beta_{3} L A R S_{3 i t}+\beta_{4} \text { BOPOS }_{4 i t}+\beta_{5} \operatorname{lnSIZES}_{5 i t} \\
+\beta_{6} H H I S_{6 i t}+\beta_{7} \operatorname{lnPDB_{7it}}+\beta_{8} I N F_{8 i t}+\varepsilon_{i t}
\end{gathered}
$$

dimana:

lnZS :Logaritma natural Z-score Bank Syariah

PLS :Pembiayaan berbasis Profit and Loss Sharing (PLS) Bank Syariah

NPF : :Non Performing Financing (NPF) Bank Syariah

LARS :Loan to Asset Ratio (LAR) Bank Syariah

BOPOS :Biaya Operasional Pendapatan Operasional (BOPO) Bank Syariah

lnSIZES :Ukuran Bank Syariah dengan menggunakan logaritma natural Total Asset Bank Syariah

HHIS :Herfindahl-Hirschman Index (HHI) Bank Syariah

lnPDB :Logaritma natural Produk Domestik Bruto (PDB)

INF :Inflasi

Model Stabilitas Sistem Perbankan Konvensional

$$
\begin{aligned}
\operatorname{lnZ} K_{i t}= & \beta_{0}+\beta_{1} B I R_{1 i t}+\beta_{2} N P L_{2 i t}+\beta_{3} L A R K_{3 i t}+\beta_{4} B O P O K_{4 i t}+\beta_{5} \ln S I Z E K_{5 i t} \\
& +\beta_{6} H H I K_{6 i t}+\beta_{7} \ln P D B_{7 i t}+\beta_{8} I N F_{8 i t}+\varepsilon_{i t}
\end{aligned}
$$

dimana:

$\operatorname{lnZK} \quad$ :Logaritma natural Z-score Bank Konvensional

BIR :BI Rate

NPL :Non Performing Loan (NPL) Bank Konvensional

LARK :Loan to Asset Ratio (LAR) Bank Konvensional

BOPOK :Biaya Operasional Pendapatan Operasional (BOPO) Bank Konvensional

lnSIZEK :Ukuran Bank Konvensional dengan menggunakan logaritma natural Total Asset Bank Konvensional

HHIK :Herfindahl-Hirschman Index (HHI) Bank Konvensional 


\section{HASIL DAN PEMBAHASAN}

Melalui pemilihan model regresi berdasarkan uji Chow, uji Hausman dan uji Lagrange Multiplier (LM) maka didapatkan model terbaik untuk stabilitas sistem perbankan syariah dan konvensional adalah model Random Effect. Adapun hasil regresi untuk kedua sistem perbankan tersebut dapat dilihat pada tabel berikut:

Tabel 2. Hasil Regresi Data Panel Model Random Effect Perbankan Syariah dan Konvensional

\begin{tabular}{|l|l|l|}
\hline \multicolumn{1}{|c|}{ Variabel Independen } & \multicolumn{1}{|c|}{$\begin{array}{c}\text { Z-score (stabilitas) } \\
\text { Perbankan Syariah }\end{array}$} & $\begin{array}{c}\text { Z-score (stabilitas) Perbankan } \\
\text { Konvensional }\end{array}$ \\
\hline Constanta & $-9.831155(0.4390)$ & $-13.28018(0.0000)$ \\
\hline PLS (Bank Syariah) & $-0.006011(0.0122)^{* *}$ & - \\
\hline BI Rate (Bank Konvensional) & - & $-0.026221(0.0725)^{*}$ \\
\hline NPF/NPL & $-0.034058(0.0058)^{* * *}$ & $0.011743(0.4641)$ \\
\hline LAR & $-0.014204(0.0000)^{* * *}$ & $-0.002881(0.2130)$ \\
\hline BOPO & $-0.001798(0.0407)^{* *}$ & $-0.010480(0.0000)^{* * *}$ \\
\hline lnSize & $-0.388091(0.0000)^{* * *}$ & $-0.263900(0.0069)^{* * *}$ \\
\hline HHI & $0.577654(0.8369)$ & $12.06484(0.0001)^{* * *}$ \\
\hline lnPDB & $1.428007(0.1043)^{*}$ & $1.449479(0.0000)^{* * *}$ \\
\hline Inflasi & $-0.001639(0.8947)$ & $-0.007484(0.2184)$ \\
\hline R-Squared (R $\left.{ }^{2}\right)$ & 0.600790 & 0.515871 \\
\hline Adjusted R-squared & 0.571219 & 0.480010 \\
\hline S.E. of regression & 0.189068 & 0.083393 \\
\hline F-statistic & 20.31683 & 14.38514 \\
\hline Prob(F-statistic) & $0.000000^{* * *}$ & $0.000000^{* * *}$ \\
\hline
\end{tabular}

Keterangan: ** Signifikan pada $\alpha=1 \%,{ }^{* *}$ Signifikan pada $\alpha=5 \%,{ }^{*}$ Signifikan pada $\alpha=10 \%$.

Berdasarkan tabel 2. dapat dilakukan interpretasi dimana nilai koefisien determinasi (R2) untuk perbankan syariah dan konvensional masing-masing adalah sebesar 0.600790 dan 0.571219 . Hal demikian menunjukkan bahwa sebesar $60.08 \%$ variasi variabel terikat (z-score bank syariah) mampu dijelaskan oleh masing-masing variabel bebas yang terdapat dalam model random effect. Sedangkan sisanya sebesar 39,92\% dijelaskan oleh sebab lain diluar model. Sementara itu sebesar 51,59\% variasi variabel terikat (z-score bank konvensional) mampu dijelaskan oleh masing-masing variabel bebas yang terdapat dalam model random effect. Sedangkan sisanya sebesar 48,41\% dijelaskan oleh sebab lain diluar model.

Interpretasi dari nilai probabilitas (F-statistic) untuk perbankan syariah dan konvensional adalah sebesar $0.000000<\alpha=5 \%$ sehingga hasilnya menolak $H_{0}$ atau menerima $H_{a}$. Artinya secara bersama-sama (simultan) variabel independen berpengaruh signifikan terhadap variabel dependen yakni z-score perbankan syariah dan konvensional.

Sedangkan secara parsial menunjukkan bahwa pembiayaan berbasis PLS, NPF, LAR, BOPO, dan Ukuran Bank (lnSize) berpengaruh negatif signifikan terhadap stabilitas sistem perbankan syariah. Sementara itu, variabel lnPDB mempunyai pengaruh positif signifikan terhadap stabilitas sistem perbankan syariah. Namun demikian, variabel HHI dan Inflasi tidak berpengaruh terhadap stabilitas sistem perbankan syariah. 
Hasil uji secara parsial menunjukkan bahwa variabel BI Rate, BOPO dan Ukuran Bank (lnSize) berpengaruh negatif signifikan terhadap stabilitas sistem perbankan konvensional. Sedangkan HHI dan $\ln$ PDB berpengaruh positif signifikan terhadap stabilitas sistem perbankan konvensional. Namun demikian, variabel NPL, LAR dan Inflasi tidak berpengaruh terhadap stabilitas sistem perbankan konvensional.

\subsection{Pembiayaan Berbasis Profit and Loss Sharing (PLS) Perbankan Syariah}

Berdasarkan hasil uji secara parsial menunjukkan bahwa pembiayaan berbasis PLS tidak berpengaruh terhadap stabilitas sistem perbankan syariah. Hasil yang ada pada penelitian ini tidak sesuai dengan hipotesis penelitian bahwa pembiayaan berbasis PLS mempunyai pengaruh positif terhadap stabilitas sistem perbankan syariah. Kuppusamy (2010) dalam penelitianya menemukan bahwa penggunaan pembiayaan berbasis bagi hasil (PLS) dapat meningkatkan profitabilitas bank. Hal ini dikarenakan keuntungan bank akan meningkat seiring dengan peningkatan pendapatan yang diperoleh oleh nasabah (mudharib). Profitabilitas bank yang meningkat tentu akan meningkatkan stabilitas bank dikarenakan profitabilitas juga merupakan komponen dari stabilitas bank. Namun demikian, pembiayaan berbasis PLS mempunyai pengaruh negatif terhadap stabilitas perbankan syariah. Hal demikian dikarenakan risiko pembiayaan berbasis PLS mempunyai risiko yang lebih tinggi daripada pembiayaan berbasis jual beli dan sewa. Sebagaimana dalam penelitian Khan dan Ahmed (2001) menempatkan pembiayaan murabahah sebagai pembiayaan dengan peringkat risiko terendah. Sementara pembiayaan berbasis PLS (mudharabah dan musyarakah) cenderung mempunyai peringkat risiko yang tinggi. Risiko yang dihadapi bank syariah dalam menyalurkan pembiayaan berbasis PLS adalah risiko moral hazard dan side streaming.

\subsection{Sistem Bunga Perbankan Konvensional}

BI Rate digunakan sebagai proxy sistem bunga bank konvensional mempunyai pengaruh negatif signifikan terhadap stabilitas sistem perbankan konvensional. Jika dibandingkan dengan PLS, BI Rate jauh lebih besar pengaruhnya daripada pembiayaan berbasis PLS dimana nilai koefisien PLS hanya sebesar -0.0060 sedangkan BI Rate sebesar 0.0262. Hasil yang ditunjukkan pada penelitian ini didukung dengan hasil penelitian Naceur (2003) bahwa variabel suku bunga berpengaruh negatif terhadap ROA bank konvensiol, dimana ROA merupakan komponen pembangun Z-score proxy dari stabilitas bank. Salah satu yang menjadi alasan adalah adanya beban bunga sebagaimana dalam penelitian Aviliani (2015) mengungkapkan bahwa BOPO merupakan indikator perbankan yang memiliki respon terbesar terhadap guncangan yang terjadi pada BI Rate. BOPO menggambarkan beban bunga yang harus dibayar dari pendapatan bank. Beban bunga yang harus dibayar sangat tergantung dengan BI Rate itu sendiri yang menjadi acuan penentuan baik bunga pinjaman maupun simpanan. Ketika BI Rate meningkat maka cost of fund akan naik. Dengan asumsi pendapatan operasional konstan maka rasio BOPO akan mengalami kenaikan.

\subsection{Non Performing Financing (NPF) dan Non Performing Loan (NPL)}


Rasio NPF dan NPL mencerminkan risiko portofolio kredit, dimana semakin tinggi angka rasio ini semakin tinggi profil risiko kredit bank yang pada giliranya akan mempengaruhi stabilitas bank secara keseluruhan. Berdasarkan hasil penelitian empiris NPF mempunyai pengaruh negatif signifikan terhadap stabilitas sistem perbankan syariah. Ini berarti peningkatan NPF akan menyebabkan menurunya stabilitas perbankan syariah. Hasil penelitian ini sejalan dengan penelitian yang dilakukan oleh Azhari dan Humayon (2016) yang menemukan bahwa NPF berpengaruh negatif signifikan terhadap stabilitas perbankan Islam di Malaysia. Demikian pula sejalan dengan hasil penelitian Ghenimi, dkk. (2017) yang menemukan bahwa risiko kredit mempunyai pengaruh negatif signifikan terhadap stabilitas perbankan Islam di MENA (Middle East and North Africa). Namun demikian, dalam penelitian ini mendapatkan hasil yang berbeda pada NPL bank konvensional. Hasilnya menunjukkan bahwa NPL tidak berpengaruh terhadap stabilitas sistem perbankan konvensional. Berdasarkan kajian stabilitas keuangan Bank Indonesia (2016) bank cenderung menahan ekspansi kredit untuk mengurangi risiko meningkatnya NPL. Ditengah melambatnya kredit bank konvensional, pembiayaan bank syariah justru mengalami peningkatan. Peningkatan pembiayaan paling signifikan terjadi pada pembiayaan jenis investasi dan modal kerja dimana kedua jenis pembiayaan tersebut menyumbang NPF tertinggi bank syariah (Bank Indonesia, 2016). Sehingga hal demikian berdampak pada menurunya stabilitas sistem perbankan syariah.

\subsection{Loan to Asset Ratio (LAR) Bank Syariah dan Bank Konvensional}

Berdasarkan hasil analisis regresi data panel pada penelitian ini menunjukkan bahwa variabel LAR berpengaruh negatif signifikan terhadap stabilitas sistem perbankan syariah. Hal demikian mempunyai indikasi bahwa peningkatan variabel LAR dapat menurunkan stabilitas sistem perbankan syariah. Hasil yang ditunjukkan pada penelitian ini sejalan dengan hasil penelitian Siti, dkk. (2012) dan Allen, dkk. (2008) yang menemukan bahwa LAR berhubungan negatif terhadap Z-score yang merupakan proxy dari stabilitas perbankan. Demikian pula Cihak dan Hesse (2008) dalam penelitianya menggunakan sampel 77 bank Islam dan 397 bank konvensional di 21 negara. Cihak dan Hesse (2008) menemukan fakta bahwa rata-rata LAR bank Islam lebih tinggi daripada LAR bank konvensional. Pengambilan risiko yang tinggi dengan menempatkan sebagian besar aset pada pembiayaan mengakibatkan berkurangnya likuiditas yang dimiliki oleh bank untuk memenuhi kewajibanya. Hal demikian berdampak pada stabilitas perbankan Islam, dimana hasil regresi menunjukkan LAR berpengaruh negatif terhadap stabilitas perbankan Islam. Sementara itu pada penelitian ini menemukan hasil yang berbeda untuk bank konvensional. Berdasarkan hasil regresi data panel random effects, variabel LAR tidak berpengaruh terhadap Z-score bank konvensional yang merupakan proxy dari stabilitas bank. Namun demikian, variabel LAR memiliki tanda koefisien negatif yang mengindikasikan bahwa peningkatan variabel LAR akan menurunkan stabilitas perbankan konvensional tetapi tetap tidak mempunyai pengaruh signifikan. Berdasarkan kajian stabilitas Bank Indonesia (2016) bank konvensional menahan 
ekspansi kredit untuk menjaga tingkat NPL yang masih cenderung meningkat. Mengurangi jumlah kredit tentu akan menurunkan tingkat rasio LAR yang mengindikasikan menurunya risiko likuiditas, sehingga wajar LAR bank konvensional tidak mempunyai pengaruh signifikan terhadap stabilitas sistem bank konvensional.

\subsection{Biaya Operasional Pendapatan Operasional (BOPO) Bank Syariah dan Bank Konvensional}

Tingkat efisiensi suatu bank sangat erat hubunganya dengan stabilitas bank tersebut. Semakin bank tersebut efisien maka risiko bank untuk default atau kebangkrutan akan semakin menurun. Pada penelitian ini, variabel biaya operasional terhadap pendapatan operasional (BOPO) digunakan sebagai proxy dari tingkat efisiensi yang dimiliki oleh perbankan. Berdasarkan hasil analisis regresi data panel random effects model, BOPO bank syariah dan bank konvensional berpengaruh negatif signifikan terhadap stabilitas kedua sistem perbankan tersebut. Hasil penelitian ini sejalan dengan hasil penelitian Azhari dan Humayon (2016) yang melakukan penelitian di Malaysia demikian pula Umar dan Shakhboz (2009) yang meneliti stabilitas bank Islam dan konvensional di 8 Negara yakni Bahrain, Kuwait, Qatar, Saudi Arabia, United Arab Emirates, Pakistan, Malaysia, and United Kingdom. Kedua penelitian tersebut menemukan bahwa risiko efisiensi berpengaruh negatif signifikan terhadap stabillitas perbankan. Penyebab utama pengaruh negatif BOPO terhadap stabilitas bank syariah dan konvensional adalah menurunya tingkat efisiensi kedua industri perbankan tersebut.

\subsection{Ukuran Bank Syariah dan Bank Konvensional}

Secara teoritis, semakin besar ukuran bank, maka semakin baik kemampuan Sumber Daya Manusianya, infrastrukturnya, dan manajemen risikonya, sehingga berdampak positif terhadap stabilitas bank. Leaven, dkk. (2014) dalam penelitianya mengungkapkan bahwa bank-bank besar mendapatkan keuntungan dari skala jangkauan yang lebih luas daripada bank kecil sehingga hal ini dapat mempengaruhi model bisnis dan kinerja mereka. Namun demikian, hasil pada penelitian ini menunjukkan perbedaan dengan teori. Total aset bank yang dijadikan proxy ukuran bank syariah dan konvensional mempunyai pengaruh negatif signifikan terhadap stabilitas bank syariah dan konvensional. Ini artinya semakin besar ukuran bank syariah dan konvensional maka semakin menurun tingkat stabilitas kedua sistem perbankan tersebut. Hasil pada penelitian ini sejalan dengan hasil penelitian Azhari dan Humayon (2016) yang menemukan bahwa ukuran bank Islam dan konvensional berpengaruh negatif signifikan terhadap stabilitas bank Islam dan konvensional di Malaysia. Demikian pula Ghenimi, dkk. (2017) yang menemukan bahwa ukuran bank mempunyai pengaruh negatif signifikan terhadap stabilitas perbankan Islam di MENA (Middle East and North Africa). Temuan pada penelitian ini juga mendukung hasil penelitian yang dilakukan oleh Cihak dan Hesse (2008) bahwa terjadinya instabilitas pada perbankan Islam dengan aset besar. Sebaliknya, menunjukkan kestabilan pada perbankan Islam dengan aset kecil. Hal demikian dapat dijelaskan bahwa kedua sistem 
perbankan baik bank syariah maupun bank konvensional mencerminkan ketidakmampuan dalam mengelola aset yang lebih besar. Semakin besar ukuran suatu bank membutuhkan manajemen risiko yang lebih baik karena semakin besar aset suatu bank maka semakin besar pula risikonya.

\subsection{Tingkat Persaingan Bank Syariah dan Bank Konvensional}

Berdasarkan hasil regresi data panel, variabel HHI (Herfindahl Hirschman Index) yang merupakan proxy dari tingkat persaingan perbankan tidak mempunyai pengaruh signifikan terhadap stabilitas perbankan syariah. Tidak berpengaruhnya tingkat persaingan antar sesama bank syariah terhadap stabilitas bank lebih disebabkan market share bank syariah yang masih jauh lebih rendah daripada market share bank konvensional. Tercatat market share aset perbankan syariah pada tahun 2016 adalah sebesar 4,96\% (Bank Indonesia, 2016). Rendahnya market share bank syariah terhadap perbankan nasional mengakibatkan bank syariah lebih bersaing dengan bank konvensional yang menguasai market share. Sebagaimana dalam penelitian Rifki (2010) yang mengungkapkan bahwa bank syariah rentan terhadap risiko likuiditas yang disebabkan oleh fluktuasi tingkat suku bunga bank konvensional. Hal demikian terkait dengan risiko berpindahnya nasabah dari bank syariah ke bank konvensional (displace commercial risk) sebagai dampak dari rendahnya tingkat bagi hasil yang ditawarkan oleh bank syariah dibandingkan dengan suku bunga deposito bank konvensional.

Sementara itu, dalam penelitian ini menunjukkan hasil yang berbeda pada perbankan konvensional. Indeks persaingan yang diukur dengan HHI mempunyai pengaruh positif signifikan terhadap stabilitas perbankan konvensional. Hal tersebut mengindikasikan bahwa semakin tinggi tingkat persaingan maka stabilitas bank akan meningkat. Hasil yang ditunjukkan pada penelitian ini juga sejalan dengan penelitian Ali dan Zaheer (2012) yang menemukan bahwa tingkat persaingan berpengaruh positif signifikan terhadap stabilitas bank komersial (konvensional) di Pakistan. Hasil yang ditunjukkan pada penelitian ini mendukung konsep competition-stability yaitu kompetisi yang semakin ketat justru dapat meningkatkan stabilitas bank. Boyd dan Nicolo (2005) menyatakan bahwa semakin besar kekuatan (market power) sebuah bank di pasar kredit dapat menciptakan risiko yang semakin besar pula karena tingkat suku bunga kredit yang semakin tinggi dapat membuat peminjam menjadi lebih sulit untuk membayar kredit tersebut dan meningkatkan moral hazard para peminjam untuk menggunakan dana kredit tersebut kedalam proyek-proyek yang lebih beresiko. Sebaliknya semakin ketat persaingan dapat menawarkan suku bunga yang kompetitif sehingga akan mengurangi terjadinya risiko kredit yang disebabkan oleh ketidakmampuan nasabah dalam melakukan pembayaran.

\subsection{Produk Domestik Bruto (PDB)}

Pada perkembanganya pertumbuhan ekonomi Indonesia mengalami perlambatan dari tahun 2012 - 2016. Perlambatan pertumbuhan ekonomi tersebut berdampak pada menurunya kinerja korporasi sehingga mengakibatkan berkurangnya kemampuan membayar kewajibanya kepada pihak perbankan yang pada akhirnya meningkatkan 
risiko kredit macet. Perlambatan pertumbuhan ekonomi mengakibatkan perbankan mengurangi ekspansi kreditnya sebagai bentuk mitigasi risiko. Oleh sebab itu dalam penelitian ini menemukan pengaruh positif signifikan variabel PDB terhadap stabilitas sistem perbankan syariah dan konvensional. Hal tersebut mengindikasikan bahwa semakin melambatnya pertumbuhan ekonomi maka kondisi stabilitas perbankan juga akan ikut menurun. Hasil yang ditunjukkan pada penelitian ini sejalan dengan hasil penelitian Umar dan Shakhboz (2009) yang meneliti stabilitas bank Islam dan konvensional di 8 Negara yakni Bahrain, Kuwait, Qatar, Saudi Arabia, United Arab Emirates, Pakistan, Malaysia, dan United Kingdom. Hasil penelitian Umar dan Shakhboz (2009) menemukan bahwa PDB berpengaruh positif signifikan terhadap stabilitas perbankan. Demikian pula Siti Rohaya, dkk. (2012) yang melakukan penelitian di Malaysia menemukan bahwa PDB berpengaruh positif signifikan terhadap stabilitas perbankan.

\subsection{Inflasi}

Inflasi dapat didefinisikan sebagai kenaikan harga umum secara terus menerus dan persisten dari suatu perekonomian. Inflasi yang tinggi tentu akan menyebabkan menurunya pendapatan rill masyarakat sehingga standar hidup masyarakat juga turun, hal ini akan berdampak negatif terhadap kinerja perekonomian secara keseluruhan baik sektor rill maupun sektor finansial. Dengan demikian tingginya tingkat inflasi cenderung berpengaruh negatif terhadap stabilitas bank. Sementara itu, hasil penelitian ini menunjukkan Inflasi tidak mempunyai pengaruh signifikan terhadap stabilitas bank syariah dan bank konvensional. Namun demikian masih sejalan dengan teori bahwa inflasi mempunyai hubungan negatif terhadap stabilitas bank. Hal ini dapat dilihat dari tanda koefisien pengaruh inflasi terhadap stabilitas bank syariah dan bank konvensional adalah negatif. Tidak berpengaruhnya inflasi terhadap stabilitas bank syariah dan bank konvensional lebih disebabkan selama periode observasi kondisi inflasi Indonesia relatif terjaga. Pasca krisis keuangan 2008 kondisi inflasi Indonesia relatif terjaga. Selama kurun waktu 2010-2016 tercatat inflasi tertinggi yaitu pada tahun 2014 sebesar 8,34\% sedangkan inflasi terendah yaitu pada tahun 2016 sebesar 3,02\% (Bank Indonesia, 2016). Tingkat inflasi tersebut termasuk dalam kategori ringan yaitu dibawah angka 10\% dalam setahun. Sehingga kenaikanya tidak terlalu berpengaruh terhadap stabilitas perbankan syariah dan konvensional.

\subsection{Analisis Perbandingan Stabilitas Sistem Perbankan Syariah dan Konvensional}

Terdapat tiga komponen yang membangun Z-score seperti ROA, standar deviasi ROA $\left(\sigma_{R O A}\right)$, dan CAR. Melalui perhitungan ketiga komponen tersebut, maka didapat Z-score yang mengindikasikan stabilitas sistem perbankan syariah dan konvensional. Adapun Z-score kedua sistem perbankan tersebut dapat dilihat pada gambar berikut: 


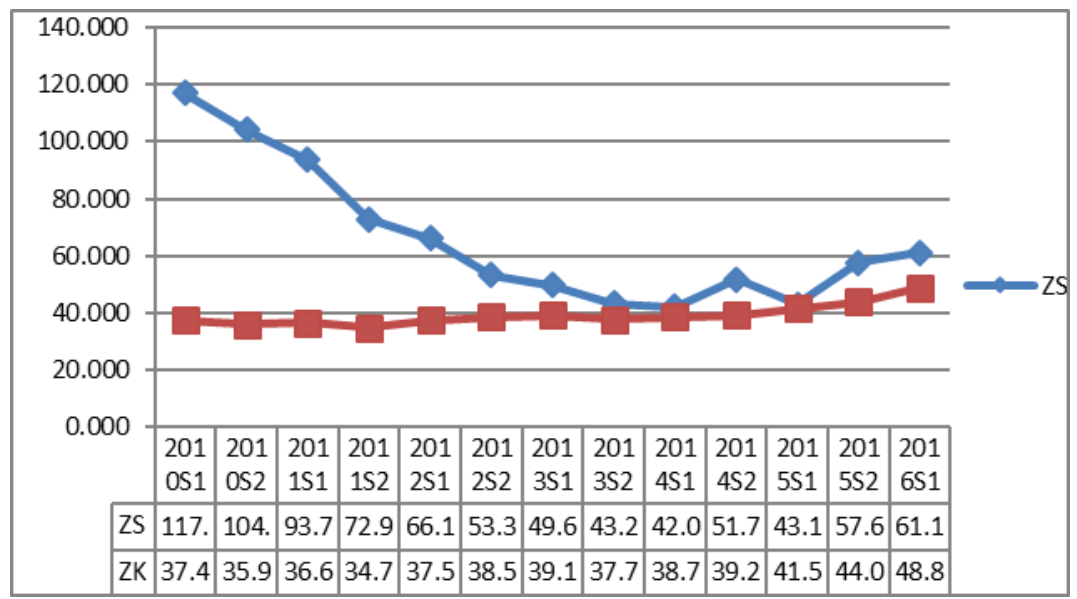

Sumber: Laporan Publikasi Perbankan, OJK 2016 (data diolah)

\section{Gambar 2. Stabilitas (Z-score) Perbankan Syariah dan Konvensional}

Berdasarkan Gambar 2. Z-score perbankan syariah cenderung mengalami tren penurunan. Nilai Z-score tertinggi bank syariah pada tahun 2010 semester 1 yakni sebesar 117,20 mengalami tren penurunan hingga tahun 2014 semester 1 yang merupakan Z-score terendah bank syariah yakni sebesar 42,07. Meskipun demikian, ditengah kondisi perekonomian yang sedang melambat bank syariah mampu meningkatkan stabilitasnya. Hal ini dapat dilihat dari nilai Z-score bank syariah pada tahun 2015 semester 1 yakni sebesar 43,12 meningkat hingga tahun 2016 semester 1 yakni sebesar 61,19. Sementara itu, berdasarkan Gambar 2. dapat dilihat pula Z-score bank konvensional yang berfluktuasi namun cenderung sedikit mengalami peningkatan. Z-score terendah bank konvensional yakni pada tahun 2011 semester 2 sebesar 34,72. Sedangkan Z-score tertinggi bank konvensional yakni pada tahun 2016 semester 1 sebesar 48,83.

Untuk melihat apakah terdapat perbedaan yang signifikan antara Z-score bank syariah dan Z-score bank konvensional, maka dilakukan uji independent sample t-tests Mann-Whitney. Digunakan t-tests tipe Mann-Whitney dikarenakan data bersifat non parametrik. Pengujian dilakukan dengan menggunakan SPSS 16, dan hasilnya dapat dilihat pada tabel berikut:

Tabel 3. Hasil Uji Independent Sample T-Tests Mann-Whitney Z-score

\begin{tabular}{|l|l|}
\multicolumn{2}{c}{ Test Statistics $^{\mathrm{a}}$} \\
\hline Mann-Whitney U & Z-SCORE \\
Wilcoxon W & 4907.000 \\
Z & 11810.000 \\
Asymp. Sig. (2-tailed) & .3 .742 \\
\hline
\end{tabular}

a. Grouping Variable: BANK

Sumber: Data diolah

Berdasarkan Tabel 3. dapat diketahui nilai Asymp.Sig (2-tailed) adalah sebesar 0.000, karena nilai Asymp.Sig (2-tailed) $0.000<0.01$, maka sesuai dengan pengambilan keputusan dalam uji Mann-Whitney dapat disimpulkan bahwa menolak $\mathrm{H}_{0}$ atau menerima $\mathrm{H}_{\alpha}$. Hal ini mengandung pengertian bahwa terdapat perbedaan yang 
signifikan antara Z-score bank syariah dan Z-score bank konvensional. Perbedaan signifikan stabilitas kedua sistem perbankan tersebut dapat dilihat dari perbedaan nilai rata-rata Z-score bank syariah adalah sebesar 65.86 jauh lebih tinggi dibandingkan dengan Z-score bank konvensional yang hanya sebesar 39.25. Hasil rata-rata Z-score dalam penetian ini sejalan seperti yang diperoleh Cihak dan Hesse (2008) yang melakukanya secara cross country bahwa rata-rata Z-score bank Islam lebih besar daripada bank komersial (konvensional) walaupun besarnya rata-rata Z-score tersebut didominasi oleh small islamic bank memiliki rata-rata Z-score yang lebih tinggi dari large islamic bank. Demikian pula sejalan dengan penelitian Siti, dkk. (2012) yang meneliti perbandingan stabilitas bank Islam dan bank konvensional di Malaysia, serta Ali dan Zaheer (2009) yang meneliti perbandingan stabilitas bank Islam dan bank konvensional di Pakistan. Kedua penelitian tersebut menghasilkan kesimpulan bahwa rata-rata nilai Z-score bank Islam lebih tinggi daripada rata-rata Z-score yang diperoleh oleh bank konvensional. Dalam penelitian ini menghasilkan kesimpulan yang sama bahwa stabilitas sistem bank syariah lebih baik daripada stabilitas sistem bank konvensional. Mengandung pengertian pula bahwa probabilitas kebangkrutan bank konvensional lebih tinggi daripada bank syariah.

Sementara itu guna memperkuat hasil temuan tersebut dapat dilakukan dengan membandingkan intersep per individu bank syariah dan konvensional. Munculnya model random effect didasarkan pada pemikiran hasil estimasi intersep dan koefisien regresi terdapat kemungkinan perbedaan antar individu dan waktu. Intersep merupakan nilai rata-rata pada variabel dependen yaitu z-score (stabilitas bank) apabila nilai pada variabel independen bernilai nol. Adapun perbandingan tingkat stabilitas per individu bank syariah dan bank konvensional berdasarkan hasil intersep adalah sebagai berikut.

\section{Tabel 4. Perbandingan Stabilitas Sistem Perbankan Syariah dan Konvensional} Berdasarkan Intersep

\begin{tabular}{|l|l|}
\hline \multicolumn{1}{|c|}{ NAMA BANK } & \multicolumn{1}{c|}{ INTERSEP } \\
\hline PT. Bank BCA Syariah & 1,26076 \\
\hline PT. Bank Muamalat Indonesia & 0,04684 \\
\hline PT. Bank Syariah Bukopin & $-0,04879$ \\
\hline PT. Bank BRI Syariah & $-0,10423$ \\
\hline PT. Bank Syariah Mandiri & $-0,20463$ \\
\hline PT. Bank Jabar Banten Syariah & $-0,92371$ \\
\hline PT. Bank Panin Syariah & $-1,46707$ \\
\hline PT. Bank Mega Syariah & $-1,60297$ \\
\hline PT. Bank BNI Syariah & $-1,99857$ \\
\hline PT. Bank Central Asia, Tbk & $-12,19044$ \\
\hline PT. Bank Tabungan Negara (Persero), Tbk & $-12,89595$ \\
\hline PT. Bank Mandiri (Persero), Tbk & $-12,92232$ \\
\hline PT. Bank Rakyat Indonesia (Persero), Tbk & $-13,04259$ \\
\hline PT. Bank Negara Indonesia (Persero), Tbk & $-13,25947$ \\
\hline
\end{tabular}




\begin{tabular}{|l|l|}
\hline \multicolumn{1}{|c|}{ NAMA BANK } & INTERSEP \\
\hline PT. Bank Maybank Indonesia, Tbk & $-13,33461$ \\
\hline PT. Bank Mega, Tbk & $-13,80873$ \\
\hline PT. Bank CIMB Niaga, Tbk & $-13,99438$ \\
\hline PT. Bank Permata, Tbk & $-14,07314$ \\
\hline
\end{tabular}

Sumber: Data diolah

Berdasarkan Tabel 4. dapat dilihat tingkat stabilitas tertinggi adalah PT. Bank BCA Syariah dengan intersep sebesar 1,26076. Sementara itu tingkat stabilitas terendah adalah PT. Bank Permata, Tbk sebesar -14.07314. Jika dibandingkan stabilitas kedua sistem perbankan tersebut, rata-rata dari keseluruhan bank syariah mempunyai tingkat kestabilan yang jauh lebih baik daripada bank konvensional. Oleh karena itu hasil yang ditunjukkan pada penelitian ini sesuai dengan hipotesis penelitian bahwa stabilitas sistem perbankan syariah jauh lebih baik daripada stabilitas sistem perbankan konvensional.

\section{PENUTUP}

\subsection{Kesimpulan}

Hasil regresi data panel dengan menggunakan model random effects menunjukkan bahwa variabel pembiayaan berbasis PLS, NPF, LAR, BOPO, Ukuran Bank, HHI, PDB dan Inflasi secara simultan berpengaruh signifikan terhadap stabilitas sistem perbankan syariah. Sementara itu hasil uji secara parsial menunjukkan bahwa pembiayaan berbasis PLS, NPF, LAR, BOPO, dan Ukuran Bank berpengaruh negatif signifikan terhadap stabilitas sistem perbankan syariah. Sementara itu, variabel PDB mempunyai pengaruh positif signifikan terhadap stabilitas sistem perbankan syariah. Namun demikian, variabel HHI dan Inflasi tidak berpengaruh terhadap stabilitas sistem perbankan syariah.

Melalui regresi data panel model random effect maka diperoleh hasil yang menunjukkan bahwa variabel BI Rate, NPL, LAR, BOPO, Ukuran Bank, HHI, PDB dan Inflasi secara simultan berpengaruh signifikan terhadap stabilitas sistem perbankan konvensional. Sementara itu berdasarkan hasil uji secara parsial menunjukkan bahwa variabel BI Rate, BOPO dan Ukuran Bank berpengaruh negatif signifikan terhadap stabilitas sistem perbankan konvensional. Sedangkan HHI dan PDB berpengaruh positif signifikan terhadap stabilitas sistem perbankan konvensional. Namun demikian, variabel NPL, LAR dan Inflasi tidak berpengaruh terhadap stabilitas sistem perbankan konvensional

Berdasarkan hasil uji Mann-Whitney menunjukkan bahwa rata-rata z-score perbankan syariah lebih tinggi daripada perbankan konvensional. Hal tersebut mengindikasikan bahwa perbankan syariah memiliki stabilitas yang lebih baik daripada perbankan konvensional. Memperkuat hasil temuan tersebut, melalui perbandingan intersep per individu bank menunjukkan bahwa rata-rata bank syariah mempunyai nilai intersep lebih tinggi daripada bank konvensional. Nilai intersep bank syariah yang 
tinggi mengindikasikan bahwa bank syariah mempunyai tingkat stabilitas yang lebih baik daripada bank konvensional.

\subsection{Saran}

Dengan terbuktinya bahwa bank syariah mempunyai tingkat kestabilan yang lebih baik daripada bank konvensional. Maka diharapkan adanya kerjasama yang berkesinambungan dan bersinergi antara pemerintah, bank sentral dan seluruh lapisan masyarakat untuk mendukung upaya percepatan market share bank syariah. Meskipun demikian bank syariah harus selalu memperhatikan faktor internal dan eksternal yang dapat mempengaruhi kondisi stabilitasnya. Terutama pembiayaan berbasis bagi hasil yang mempunyai tingkat risiko tinggi. Bank syariah dituntut untuk melakukan monitoring dan pendampingan yang lebih ketat terhadap pembiayaan yang diberikan untuk menghindari risiko kredit macet dan mengurangi beban biaya operasional. Sementara itu, manajemen bank konvensional diharapkan untuk mengelola spread antara suku bunga Dana Pihak Ketiga (DPK) dan suku bunga kredit sehingga tidak menjadi beban biaya operasional yang dapat mengancam stabilitas. Pada penelitian selanjutnya diharapkan dapat menggunakan berbagai indeks pengukuran stabilitas sistem perbankan seperti Banking Condition Index, Banking Stress Index dan Banking Stability Index sehingga memperoleh hasil yang lebih akurat dalam membandingkan stabilitas sistem perbankan syariah dan konvensional.

\section{DAFTAR PUSTAKA}

Ahmed, H. 2002. A microeconomic model of Islamic banking. Research Paper Islamic Research and Training Institute.

Akram, Q.F. dan Eithreim. 2008. Flexible Inflation Targeting and Financial Stability: Is It Enough to Stabilize Inflation and Output?. Journal of Banking and Finance 32 (7) $1242-1254$

Ali, M.S., and Zaheer, A. 2012. Financial Stability of Islamic Banking in Pakistan: An Empirical Study. African Journal of Business Management. Vol. 6 (10)

Allen, N.B. Klapper, L.F. dan Ariss, R.T. 2008. Bank Competition and Financial Stability. IMF Working Paper, WPS 4696

Aviliani, Hermanto, S. Tubagus. 2015. The Impact of Macroeconomic Condition On The Bank's Performance In Indonesia. Buletin Ekonomi Moneter dan Perbankan, Volume 17, No. 4.

Azhari, W.M. dan Humayon, D. 2016. Stability of Islamic Versus Conventional Banks: A Malaysian Case. Jurnal Ekonomi Malaysia 50(1) 20016 111-132

Bank Indonesia. 2010. Krisis Global dan Penyelamatan Sistem Perbankan Indonesia. $\begin{array}{lllll}\text { Diambil tanggal } & 5 & \text { Juli } & 2017 & \text { dari }\end{array}$ www.bi.go.id/id/publikasi/lain/artikel/pages/buku_krisis.

Bank Indonesia. 2016. Kajian Stabilitas Keuangan No.27 September 2016. Jakarta: Departemen Kebijakan Makroprudensial

Bank Indonesia. 2017. Stabilitas Sistem Keuangan. Diambil tanggal 5 Juli 2017 dari https://www.bi.go.id/id/perbankan/ssk/ikhtisar/pentingnya/Contents/Defaul t.aspx 
Boyd, J.H. Levine, R. dan Smith, B.D. 2001. The Impact of Inflation on Financial Sector Performance. Journal of Monetary Economics, 47, 221-248

Boumediene, A. dan Caby, J. 2010. The Stablity of Islamic Banks During Subprime Crisis. Available at SSRN: http://ssrn.com/abstract=1524775. Diakses 24 Mei 2017.

Cihak, M. and Hesse, H. 2008. Islamic Banks and Financial Stability: An Empirical Analysis. IMF Working Paper WP//08/16

Deutsche Bundesbank. 2003. Report on the stability of the German financial system, Monthly Report, Frankfurt, December

Drifill, J. Rotondi, Z. Savona, P. dan Zazzara, C. 2006. Monetary Policy and Financial Stability: What Rule for Futures Market? Journal of Financial Stability 95-112

Ghenimi, A. Chaibi, H. dan Ali, M. 2017. The Effects of Liquidity Risk and Credit Risk on Bank Stability: Evidence From the Mena Region. Borsa Istanbul Review

Hasan, M. \& Dridi, J. 2010. The effects of the global crisis on Islamic and conventional banks: A comparative study. IMF Working Paper, WP/10/201, 1-46.

Houben, A. Kakes, J. dan Schinasi, G. 2004. Towards a Framework for Safeguarding Financial Stability. IMF Working Paper WP/04/01

Korbi, F., Bougatef, K., 2017. Regulatory Capital and Stability of Islamic and Conventional Banks. Int. J. Islam. Middle East. Financ. Manag. 10, 312-330.

Kraft, E., dan Galac, T. 2007. Deposits Inteest Rates, Asset Risk and Bank Failure in Croatia. Journal of Financial Stability 312-336

Kuppusamy, M. Saleh, A. and Samudhram, A. 2010. Measurement of Islamic banks performance using a shariah conformity and profitability model. international association for Islamic economics. Review of Islamic Economics, vol. 13, no. 2, pp. 35-48.

Laeven, L., Ratnovski, L., dan Tong, H. 2014. Bank size and systemic risk: Some international evidence. International Monetary Fund.

Minsky, H.P. 1992. The Financial Instability Hypothesis. Levy Economics Institute Working Paper No.74.

Naceur, S.B. 2003. The Determinants of The Tunisian Banking Industry Profitability: Panel Evidence. Department of Finance, Université Libre de Tunis.

Nawal, H. dan Abbas, E. H. 2013. Islamic finance: Is it a viable option to restrain financial crisis?. Interdisciplinary Journal of Contemporary Research in Business, Vol.5.

Nur, I. 2014. Pengaruh Ekonomi Makro Terhadap Stabilitas Bank Konvensional dan Syariah: Pendekatan Banking Stability Index (BSI) Periode 2005-2013. Yogyakarta: Tesis UII

Parashar, S. dan Venkatesh, J. 2010. How did Islamic banks do during global financial crisis. Banks and Bank Systems Volume 5, Issue 4.

Rajhi, W. dan Hassairi, A.S. 2013. Islamic Banks and Financial Stability: A Comparative Empirical Analysis Between MENA and Southest Asian Countries. Region of Development 37-2013

Rashid, A., Yousaf, S., Khaleequzzaman, M., 2017. Does Islamic Banking Really Strengthen Financial Stability? Empirical Evidence from Pakistan. Int. J. Islam. 
Middle East. Financ. Manag. Vol. 10. https://doi.org/10.1108/IMEFM-11-20150137

Rifki, Ismal. 2010. The Management of Liquidity Risk In Islamic Banks: The Case Of Indonesia. United Kingdom: Durham Thesis, Durham University

Siti, R.M. Norsilawati, M.H. dan Roza H.Z. 2013. Comparison on Stability between Islamic and Conventional Banks in Malaysia. Journal of Islamic Economics, Banking and Finance, Vol.9, No.3

Schinasi, Garry J. 2005. Preserving Financial Stability, Economic Issues 36, International Monetary Fund

Todaro Micheal P dan Stephen Smith. 2008. Pembangunan Ekonomi. Jakarta: Erlangga.

Trabelsi, M.A., Trad, N., 2017. Profitability and risk in interest-free banking industries: a dynamic panel data analysis. Int. J. Islam. Middle East. Financ. Manag. 10, 454469 https://doi.org/ 10.1108/ IMEFM -05-2016-0070

Umar Islam Muhammad and Kozokov Shakhboz. 2009. Stability of Islamic and Conventional banks, an empirical comparative analysis. Master Thesis Spring 2009, School of Economics and Management Lund University

World Bank. 2019. Financial Stability. Diambil tanggal 3 Juli 2019 dari http:// www. worldbank. org/en/ publication/ gfdr/background/ financial-stability

Zamir Iqbal dan Abbas Mirakhor. 2015. Pengantar Keuangan Islam: Teori dan Praktik. Jakarta: Kencana 